\title{
PENGARUH TINGKAT PAJAK EFEKTIF PERUSAHAAN TERHADAP PEMBERHENTIAN DIREKTUR UTAMA
}

\author{
Arifah Fibri Andriani ${ }^{a}$, Goradok Pande Raja Sinabutar ${ }^{b}$
}

a Politeknik Keuangan Negara STAN, Tangerang Selatan, Indonesia. Email: arifah.fibri@stan.ac.id b Direktorat Jenderal Pajak, Jakarta Selatan, Indonesia. Email: dedekfidelis@gmail.com

\section{ABSTRACT}

This study aims to determine the effect of the company's effective tax rate on forced president director turnover. Prior studies find that the company's effective tax rate is used continuously by shareholders to assess the performance of top manager (president director), then used as the basis of making decisions whether to hire or to fire the top manager. The effective tax rate of company is measured using accountancy effective tax rate (ETR) and cash effective tax rate (Cash ETR). By using 90 companies listed on the Indonesia Stock Exchange (IDX) as the samples, selected after going through purposive sampling stages, with firm-years starting from 2012 to 2016, this study finds that the company's effective tax rate (both ETR and Cash ETR) does not affect the forced president director turnover.

Keywords: Effective Tax Rate, Forced President Director, Tax Avoidance

\section{ABSTRAK}

Penelitian ini dilakukan untuk mengetahui pengaruh tingkat pajak efektif perusahaan terhadap pemberhentian direktur utama. Penelitian-penelitian terdahulu menemukan bahwa tingkat pajak efektif perusahaan digunakan secara berkesinambungan oleh pemegang saham untuk menilai kinerja manajer puncak (direktur utama), yang kemudian dijadikan sebagai dasar untuk mengambil keputusan apakah akan mempertahankan atau memecat manajer puncak. Tingkat pajak efektif perusahaan diukur dengan menggunakan tingkat pajak efektif akuntansi (effective tax rate/ETR) dan tingkat pajak efektif kas (cash effective tax rate/Cash ETR). Dengan menggunakan sampel berupa 90 emiten yang terdaftar di Bursa Efek Indonesia (BEl), yang dipilih setelah melalui tahapan purposive sampling, dengan firm-year mulai dari 2012 s.d. 2016, penelitian ini menunjukkan bahwa tingkat pajak efektif (baik ETR maupun Cash ETR) perusahaan tidak berpengaruh terhadap pemberhentian manajer puncak.

Kata Kunci: Tingkat Pajak Efektif, Pemberhentian Direktur Utama, Penghindaran Pajak 


\section{PENDAHULUAN}

\subsection{Latar Belakang}

Konsep teori keagenan menurut Alchian dan Demsetz dalam Panda dan Leepsa (2017, h. 76) menyimpulkan bahwa perusahaan didasarkan pada kontrak antara principal dan agent. Principal adalah pihak yang memiliki perusahaan serta mengangkat dan mempekerjakan seorang agent agar melakukan tugas untuk kepentingan principal, sedangkan agent adalah pihak yang mengelola perusahaan atas nama principal. Widyaningdyah (2001, h. 91) menyatakan bahwa perusahaan yang modalnya terdiri atas saham, pemegang saham bertindak sebagai principal sedangkan manajer puncak bertindak sebagai agent.

Penelitian terdahulu yang dilakukan oleh Dyreng, Hanlon dan Maydew (2010); Rego dan Wilson (2012); Chyz (2013); Gaertner (2014); Chyz et al. (2015); serta, Olsen dan Stekelberg (2015) menunjukkan bahwa manajer puncak berpengaruh terhadap aspek perpajakan perusahaan, yang tercermin dari tingkat pajak efektif (effective tax rate) perusahaan. Hal tersebut didukung dengan survei yang dilakukan oleh Ernst \& Young dalam Chyz dan Gaertner (2016, h. 10) yang menunjukkan hasil bahwa manajer puncak (chief executive officer/CEO) berperan penting menetapkan dan mengevaluasi kebijakan pajak perusahaan.

Pajak merupakan komponen biaya material pada laporan keuangan (Dyreng, Hanlon dan Maydew, 2008, h. 22) sekaligus faktor pendorong banyak keputusan perusahaan (Lanis dan Richardson, 2011, p. 87), selanjutnya Lanis dan Richardson (2011, h. mengungkapkan bahwa keputusan manajemen yang dirancang semata-mata untuk meminimalkan pajak melalui kegiatan pajak yang agresif menjadi hal yang semakin umum dilakukan oleh perusahaan-perusahaan di seluruh dunia.

Balter dalam Zain (2008, h. 49) menyebutkan bahwa Wajib Pajak (baik Orang Pribadi maupun Badan) selalu berusaha untuk melakukan strategi untuk dapat membayar pajak yang terutang sekecil mungkin, sepanjang hal itu dimungkinkan oleh perundang-undangan perpajakan. Salah satu strategi yang dilakukan oleh perusahaan adalah dengan menerapkan penghindaran pajak (tax avoidance).

Tax avoidance adalah usaha untuk mengurangi, menghindari serta meringankan beban pajak dengan berbagai cara yang dimungkinkan oleh perundang-undangan perpajakan dengan memperhatikan ada atau tidaknya suatu akibat pajak yang ditimbulkannya (Balter dalam Zain, 2008, h. 49). Salah satu proksi yang digunakan untuk mengukur penghindaran pajak adalah tingkat pajak efektif (Dyreng, Hanlon dan Maydew, 2010, h. 1164).

Blouin dalam Chyz dan Gaertner (2016, h. 15) membuktikan bahwa perusahaan benar-benar memperhatikan tingkat pajak efektif mereka. Sementara itu, Armstrong et al. dalam Chyz dan Gaertner (2016, h. 16) menyatakan bahwa tingkat pajak efektif adalah alat ukur yang paling lazim digunakan oleh pemegang saham perusahaan untuk menilai kinerja dan pengambilan keputusan seorang 
manajer puncak karena kesederhanaan interpretasinya, kemudahan pengidentifikasiannya keuangan, dan di laporan kemudahan perhitungannya. Hasil penelitian Chyz dan Gaertner (2016, hh. 34-35) menyimpulkan bahwa pemegang saham menilai tingkat pajak efektif secara berkesinambungan lalu menggunakannya sebagai penilaian kinerja dan pengambilan keputusan apakah akan mempertahankan atau memecat manajer puncak.

Fee, Hadlock dan Pierce (2013, p. 576) membuktikan bahwa pemberhentian manajer puncak mencerminkan langkah yang secara sengaja diambil oleh pemegang saham untuk mengubah arah, strategi dan kepemimpinan perusahaan. Terdapat sejumlah penelitian yang telah meneliti pemberhentian manajer puncak dikaitkan dengan tingkat pajak efektif perusahaan. Penelitian yang dilakukan oleh Desai dan Dharmapala (2006); Hanlon dan Slemrod (2009); Chen et al. (2012); serta Graham et al. (2013) menyakini bahwa kemungkinan seorang manajer puncak diberhentikan lebih tinggi saat tingkat pajak efektif perusahaan rendah. Tingkat pajak efektif perusahaan yang rendah mengindikasikan penghindaran pajak yang tinggi. Pemegang saham memang menginginkan manajer untuk melakukan perencanaan pajak yang optimal, dengan cara menyeimbangkan antara manfaat dan biaya penghindaran pajak. Akan tetapi, penghindaran pajak yang tinggi akan meningkatkan kemungkinan otoritas pajak melakukan pemeriksaan terhadap perusahaan; serta, membuat perusahaan kehilangan reputasi (reputational penalties) sehingga perusahaan dianggap sebagai "perusahaan miskin" ("poor corporate citizen").

Penelitian yang dilakukan oleh Chyz dan Gaertner (2016, hh. 34-35) justru menunjukkan hasil sebaliknya: bahwa kemungkinan seorang manajer puncak diberhentikan lebih tinggi saat tingkat pajak efektif perusahaan tinggi. Pajak mencerminkan perpindahan kekayaan dari pemegang saham kepada otoritas pemerintah, sehingga tingkat pajak efektif perusahaan yang tinggi mencerminkan ketidakmampuan manajer puncak untuk meminimalisir pajak sehingga manajer puncak dianggap bertanggungjawab atas penurunan kekayaan pemegang saham yang disebabkan oleh tingginya pajak yang dibayar perusahaan.

Fakta yang ditemukan di Indonesia yaitu tidak terjadi pemberhentian manajer puncak (direktur utama atau presiden direktur) pada beberapa perusahaan yang mengecilkan besarnya pajak perusahaan terutang. Kasus dugaan penggelapan pajak oleh PT Asian Agri Group, misalnya. Mei 2007 Direktorat Jenderal Pajak (Ditjen Pajak) mengumumkan adanya dugaan penggelapan pajak oleh PT Asian Agri Group melalui manipulasi Surat Pemberitahuan Pajak (SPT) Tahunan terutang 2002-2005 oleh 15 anak perusahaan PT Asian Agri Group. Penggelapan pajak tersebut diduga mencapai Rp 1,3 triliun (Sp.Beritasatu.com, 11 Oktober 2010). November 2017 Kejaksaan Agung menetapkan 8 orang jajaran direksi PT Asian Agri Group sebagai tersangka (Bbc.co.uk, 8 November 2007). 
Desember 2012 Mahkamah Agung (MA) menghukum PT Asian Agri Group untuk membayar denda ke negara sebesar $\mathrm{Rp}$ 2,5 triliun atas kasus penggelapan pajak (Detik.com, 28 Desember 2012). Meskipun kasus penggelapan pajak oleh PT Asian Agri Group mulai muncul sejak tahun 2007, tidak terjadi pemecatan direktur utama di PT Asian Agri Group sampai dengan tahun 2012.

Selain pada PT Asian Agri Group, juga ditemukan beberapa fakta serupa di perusahaan PT Nusa Raya Cipta dan PT Bumi Resources Tbk. Desember 2013 majelis hakim Pengadilan Tindak Pidana Korupsi (Tipikor) memvonis dua Penyidik Pegawai Negeri Sipil (PPNS) Perpajakan yang telah terbukti secara sah menerima suap dari PT Nusa Raya Cipta untuk penghentian tindak lanjut hasil pemeriksaan bukti permulaan atas PT Nusa Raya Cipta (Cnnindonesia.com, 29 Mei 2013). Sementara itu, Desember 2010 Gayus Halomoan Tambunan mengaku menerima suap dari PT Bumi Resources Tbk. dalam persidangan di Pengadilan Negeri Jakarta Selatan terkait sidang banding PT Bumi Resources Tbk. tahun pajak 2005 (Sp.Beritasatu.com, 11 Oktober 2010). Meskipun demikian, baik PT Nusa Raya Cipta maupun PT Bumi Resources tidak melakukan pemberhentian manajer puncak.

Berdasarkan pemaparan di atas, ditemukan adanya perbedaan antara hasil penelitian terdahulu dan fakta yang terjadi di Indonesia. Oleh karena itu, penelitian ini mencoba untuk mencari jawaban apakah tingkat pajak efektif perusahaan berpengaruh terhadap pemberhentian manajer puncak.

\subsection{Ruang Lingkup (Pembatasan) Penelitian}

Pembatasan pemberhentian manajer yang dimaksud dalam penelitian ini mengikuti Chyz dan Gaertner (2016), yaitu memfokuskan pemberhentian manajer puncak yang mewakili kepemimpinan perusahaan dan bertugas untuk mengubah arah dan strategi perusahaan. Di Indonesia tugas, tanggung jawab dan wewenang tersebut dijalankan oleh direksi (Undang-Undang Nomor 40 Tahun 2007 tentang Perseroan Terbatas), dimana satu diantara anggota direksi diangkat menjadi direktur utama atau presiden direktur sebagai manajer puncak. Adapun ruang lingkup perusahaan dalam penelitian ini adalah emiten terdaftar di $\mathrm{BEl}$, dengan menggunakan data panel sejak tahun 2012 sampai dengan 2016.

Chyz dan Gaertner (2016) memfokuskan pemberhentian manajemen puncak melalui peran CEO. Sementara itu, pembatasan pemberhentian manajemen puncak dalam penelitian ini adalah direktur utama atau presiden direktur.

Variabel dan metode dari penelitian ini diambil dari penelitian Chyz dan Gaertner (2016) dengan beberapa penyesuaian. Penyesuaian terhadap variabel yang digunakan pada penelitian Chyz dan Gaertner (2016) dilakukan agar sesuai dengan kondisi perusahaan dan laporan keuangan yang berlaku di Indonesia. 


\subsection{Rumusan Masalah (Pertanyaan Penelitian)}

Berdasarkan latar belakang dan ruang lingkup (pembatasan) masalah di atas, rumusan masalah (pertanyaan penelitian) dalam penelitian ini adalah "Apakah tingkat pajak efektif perusahaan berpengaruh terhadap pemberhentian direktur utama?"

\subsection{Tujuan Penelitian}

Berdasarkan ruang lingkup (pembatasan) penelitian dan rumusan masalah (pertanyaan penelitian) di atas, tujuan penelitian ini adalah untuk mengetahui pengaruh tingkat pajak efektif perusahaan terhadap pemberhentian direktur utama.

\subsection{Manfaat (Kontribusi) Penelitian}

Penelitian ini diharapkan dapat berkontribusi positif bagi Ditjen Pajak secara umum dan khususnya bagi Account Representative (AR) dan Fungsional Pemeriksa Pajak (FPP) secara khusus. Hasil penelitian ini diharapkan dapat membantu AR dalam melakukan penyusunan rencana penggalian potensi dengan melihat pergantian direktur utama pada perusahaan-perusahaan, baik melalui pemberitaan di media maupun melalui laporan tahunan. Selain itu, hasil penelitian ini diharapkan dapat membantu FPP dengan menjadikan informasi pergantian direktur utama pada perusahaan-perusahaan sebagai bahan masukan penyusunan rencana dan

program

pemeriksaan.
Pergantian direktur utama mengindikasikan tingkat pajak efektif perusahaan yang terlalu tinggi atau tingkat pajak efektif perusahaan yang terlalu rendah.

\section{KERANGKA TEORITIS DAN PENGEMBANGAN HIPOTESIS}

\subsection{Landasan Teori}

\subsubsection{Tingkat Pajak Efektif (Effective Tax Rate)}

Dua alat ukur umum tingkat pajak efektif menurut Dyreng, Hanlon dan Maydew $(2010,1164)$ yaitu tingkat pajak efektif akuntansi (effective tax rate/ETR) dan tingkat pajak efektif kas (cash effective tax rate/Cash ETR). Tingkat pajak efektif dihitung dengan mengadopsi penelitian Armstrong et al. (2015).

Cash ETR mencerminkan pembayaran pajak aktual (cash tax paid) perusahaan sesuai basis kas pada tingkatan pre-tax income tertentu. ETR mencerminkan beban pajak akuntansi (tax expense) perusahaan sesuai basis akrual pada tingkatan pre-tax income tertentu. ETR mencakup pajak akrual untuk tujuan pelaporan keuangan, sedangkan Cash ETR hanya mencakup sejumlah besar pajak yang dibayarkan menggunakan kas, dengan tidak memperhitungkan pajak secara akrual, termasuk perubahan dalam kontinjensi pajak perusahaan. 


\subsubsection{Peran Direktur Utama dalam Tata Kelola Perusahaan Publik}

Pasal 1 angka 5 Undang-Undang Nomor 40 Tahun 2007 menyebutkan bahwa direksi adalah organ perseroan yang berwenang dan bertanggung jawab penuh atas pengurusan perseroan untuk kepentingan Perseroan, sesuai dengan maksud/tujuan perseroan serta mewakili perseroan. Emiten atau perusahaan publik wajib memiliki direksi sekurang-kurangnya dua orang anggota direksi. 1 (satu) di antara anggota direksi diangkat menjadi direktur utama atau presiden direktur (Pasal 2 ayat (2) Peraturan Otoritas Jasa Keuangan Nomor 33/POJK.04/2014).

\subsubsection{Pergantian Direktur Utama (Unforced President Director Turnover)}

Pergantian direktur utama (unforced president director turnover) adalah perubahan direktur utama yang dilakukan tidak secara dipaksakan atau terjadi secara alami, yang terjadi karena dua keadaan, yaitu meninggal dunia atau memasuki usia pensiun (Chyz dan Gaertner, 2016, h. 3) dan (Fee, Hadlock dan Pierce, 2013, h. 568). Pada penelitian ini penulis menggunakan tambahan keadaan untuk mengkategorikan sebuah perubahan sebagai pergantian direktur utama, agar sesuai dengan kondisi perusahaan dan tata kelola yang berlaku di Indonesia, yaitu perubahan jabatan seseorang yang sebelumnya adalah direktur utama menjadi salah satu dari komisaris, wakil komisaris ataupun komisaris utama perusahaan. Pergantian direktur utama tidak disebabkan oleh keadaan kritis perusahaan, yang mendorong dewan perusahaan untuk mengganti arah, strategi dan kepemimpinan perusahaan (Fee, Hadlock dan Pierce, 2013, h. 577).

\subsubsection{Pemberhentian Direktur Utama (Forced President Director Turnover)}

Pemberhentian direktur utama (forced president director turnover) adalah perubahan direktur utama yang dilakukan secara dipaksakan atau tidak alami (Chyz dan Gaertner, 2016, h. 9) dan (Fee, Hadlock dan Pierce, 2013, h. 579). Pemberhentian direktur utama disebabkan oleh krisis yang dihadapi oleh perusahaan sehingga mendorong dewan perusahaan untuk melakukan perubahaan terhadap arah, strategi dan kepemimpinan perusahaan (Chyz dan Gaertner, 2016, h. 13) sebab pemberhentian direktur utama mencerminkan langkah yang secara sengaja diambil oleh dewan perusahaan untuk mengubah arah, strategi dan kepemimpinan perusahaan (Fee, Hadlock dan Pierce, 2013, h. 578).

\subsubsection{Biaya Reputasi (Reputational Cost)}

Biaya reputasi (reputational cost) dianggap sebagai faktor yang membatasi sejauh mana perusahaan dan manajer akan meminimalkan tingkat pajak efektif perusahaan melalui praktik penghindaran pajak (tax avoidance) 
(Desai dan Dharmapala, 2006; Hanlon dan Slemrod, 2009; Chen et al., 2013; serta, Graham et al., 2013). Bukti empiris menunjukkan bahwa perusahaan akan benar-benar mempertimbangkan biaya reputasi dalam setiap pengambilan keputusan atas strategi pajaknya, sebab biaya reputasi dapat berdampak kepada manajemen puncak (dalam hal ini direktur utama) secara pribadi dan biaya reputasi dapat pula berdampak kepada perusahaan secara keseluruhan (Desai dan Dharmapala, 2006); (Austin dan Wilson, 2015); serta (Crocker dan Slemrod, 2005).

\subsubsection{Norma Sosial (Social Norms)}

Norma sosial (social norms) dianggap sebagai kontrol sosial (social control), karena norma sosial mengendalikan atau mempengaruhi perilaku seseorang, sekelompok orang atau suatu entitas, dalam masyarakat/komunitas (Martin dan Hewstone dalam Parlaungan, 2017, h. 20). Di dalam lingkungan dimana norma sosial berfungsi aktif seseorang, sekelompok orang atau suatu entitas, cenderung akan menerima hukuman, baik secara langsung maupun secara tidak langsung, oleh masyarakat jika melakukan pelanggaran.

\subsection{Kerangka Berpikir}

Pemberhentian (forced turnover) manajer puncak mencerminkan langkah yang secara sengaja diambil pemegang saham untuk mengubah arah, strategi dan kepemimpinan perusahaan.
Pemegang saham selalu menilai kepemimpinan manajer puncak sebagai agent yang memiliki wewenang dan tanggung jawab untuk bertindak atas nama perusahaan, untuk kemudian memutuskan apakah akan terus mempertahankan atau memberhentikan manajer puncak.

Terdapat sejumlah studi literatur awal yang telah membuktikan bahwa pemberhentian manajer puncak dikaitkan dengan tingkat pajak efektif perusahaan. Tingkat pajak efektif merupakan salah satu alat ukur yang umum digunakan untuk memahami kebijakan pajak yang diambil oleh perusahaan, yang dapat diawasi dan dinilai oleh pemegang saham. Bukti penelitian empiris menunjukkan bahwa biaya reputasi (reputational cost) merupakan faktor yang membatasi sejauh mana perusahaan dan manajer akan meminimalkan tingkat pajak efektif perusahaan. Asumsi tradisional biaya reputasi menyakini bahwa kemungkinan manajer puncak diberhentikan seharusnya lebih tinggi saat tingkat pajak efektif perusahaan rendah. Perusahaan yang membayar pajak terlalu rendah akan membuat perusahaan dianggap sebagai perusahaan miskin sehingga menurunkan reputasi perusahaan dan meningkatkan risiko pemeriksaan pajak. Oleh karena itu, tingkat pajak efektif perusahaan yang terlalu rendah akan meningkatkan kemungkinan manajer puncak diberhentikan.

Walaupun demikian, terdapat sejumlah studi literatur awal yang menyimpulkan bahwa pemegang saham cenderung mengharapkan perusahaan untuk mengurangi kewajiban pajak yang timbul sebab pajak merupakan 
sehingga dapat disimpulkan: pembayaran pajak adalah biaya/beban yang timbul, yang menyebabkan arus kas dan laba bersih yang lebih rendah. Tingkat pajak efektif perusahaan yang tinggi mencerminkan ketidakmampuan manajer puncak untuk meminimalisir pajak sehingga manajer puncak dianggap bertanggungjawab atas penurunan kekayaan pemegang saham yang disebabkan oleh tingginya pajak yang perusahaan.
Oleh karena itu, tingkat pajak efektif perusahaan yang terlalu tinggi akan meningkatkan kemungkinan manajer puncak diberhentikan.

Berdasarkan pemaparan tersebut di atas dapat disimpulkan bahwa tingkat pajak efektif perusahaan yang terlalu rendah atau terlalu tinggi akan meningkatkan kemungkinan pemberhentian seorang manajer puncak. Secara lebih jelas, kerangka berpikir pada penelitian ini ditunjukkan pada Gambar 1.
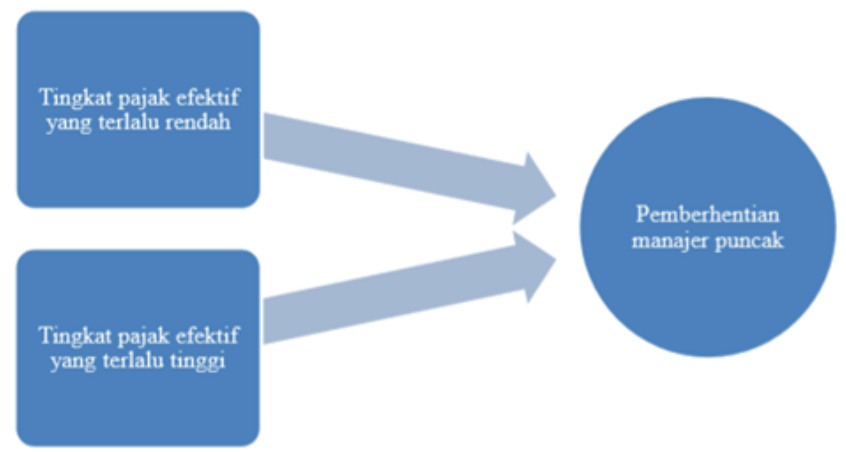

\subsection{Hipotesis Penelitian}

Variabel yang akan diteliti pengaruhnya terhadap pemberhentian direktur utama adalah tingkat pajak efektif perusahaan. Tingkat pajak efektif, baik ETR maupun Cash ETR, diketahui dengan mengadopsi penelitian Armstrong et al. (2015). ETR dihitung dari jumlah tax expense selama tiga-tahun dibagi dengan jumlah total pre-tax income selama tiga-tahun. Cash ETR dihitung dari jumlah total cash tax paid selama tiga-tahun dibagi dengan jumlah total pre-tax income selama tiga-tahun. Setelah tingkat pajak efektif dari semua perusahaan sampel diketahui, sebaran atas seluruh tingkat pajak efektif dibagi menjadi 3 (tiga) kelompok kuintil (quintile) data, yaitu Kelompok Kuintil Terendah (Quintile 1) (yang merupakan proxy dari tingkat pajak efektif perusahaan yang terlalu rendah), Kelompok Kuintil Tengah (Quintile 2, 3 dan 4) serta Kelompok Kuintil Tertinggi (Quintile 5) (yang merupakan proxy dari tingkat pajak efektif perusahaan 
yang terlalu tinggi) (Chyz dan Gaertner, 2016, h. 18).

Rendah atau tinggi tingkat pajak efektif mengindikasikan tinggi atau rendahnya tax avoidance (Jacob dan Müller, 2017, h. 5). Tingkat pajak efektif perusahaan yang rendah mengindikasikan penghindaran pajak yang tinggi. Penghindaran pajak yang tinggi akan meningkatkan kemungkinan otoritas pajak melakukan pemeriksaan terhadap perusahaan; serta, membuat perusahaan kehilangan reputasi (reputational penalties) sehingga perusahaan dianggap sebagai "perusahaan miskin" ("poor corporate citizen"). Oleh karena itu, hipotesis pertama yang diajukan dalam penelitian ini adalah sebagai berikut:

Ha1: Tingkat pajak efektif perusahaan yang terlalu rendah berpengaruh signifikan terhadap pemberhentian direktur utama.

\section{Pajak}

mencerminkan

perpindahan kekayaan dari pemegang saham kepada otoritas pemerintah, sehingga tingkat pajak efektif perusahaan yang tinggi mencerminkan ketidakmampuan manajer puncak meminimalisir pajak sehingga manajer puncak dianggap bertanggungjawab atas penurunan kekayaan pemegang saham yang disebabkan oleh tingginya pajak yang dibayar. Oleh karena itu, hipotesis kedua yang diajukan penelitian ini adalah sebagai berikut:

Ha2: Tingkat pajak efektif perusahaan yang terlalu tinggi berpengaruh signifikan terhadap pemberhentian direktur utama.

\section{METODOLOGI PENELITIAN \\ 3.1 Gambaran Umum Objek dan Alasan Pemilihan Objek}

Penelitian ini bertujuan untuk mengetahui pengaruh tingkat pajak efektif perusahaan terhadap pemberhentian direktur utama, dengan sampel berupa emiten terdaftar di BEI. Pengambilan sampel dilakukan secara purposive sampling (judgement sampling) yang merupakan bagian dari metode non-probability sampling, yaitu pemilihan sampel secara tidak acak dengan kriteria-kriteria tertentu (Sugiyono, 2016, h. 85). Oleh karena itu, anggota populasi yang tidak memenuhi syarat tidak akan dipilih sebagai sampel penelitian.

Sampel-sampel yang representatif akan diambil untuk selanjutnya diolah dan dilakukan analisis sesuai dengan metode yang telah dipilih. Kriteria sampel-sampel yang representatif mengikuti Chyz dan Gaertner (2016) dengan beberapa penyesuaian, sebagai berikut:

1. perusahaan yang terdaftar di BEl;

2. perusahaan yang memiliki data laporan keuangan lengkap dalam kurun waktu 2010-2016; dan

3. perusahaan yang dikecualikan sebagai data sampel dalam penelitian ini adalah perusahaan yang termasuk ke dalam sektor keuangan (financial), perusahaan yang mayoritas penghasilannya dikenakan PPh final, perusahaan yang memiliki penghasilan kena pajak (pre-tax income) yang negatif, perusahaan yang tidak menyampaikan laporan keuangan secara lengkap, perusahaan yang termasuk sebagai 
perusahaan kecil dan menengah (small and medium enterprise), perusahaan asing (foreign company), perusahaan yang memiliki ekuitas (equity) yang negatif, perusahaan yang ukuran (size) tidak diketahui, perusahaan yang ETR atau Cash ETR tidak diketahui, dan perusahaan yang Kemampuan Manajerial (Managerial Ability) tidak diketahui. Kriteria firm-year yang termasuk dalam sampel penelitian ini mengikuti Chyz dan Gaertner (2016, h. 14) dengan beberapa penyesuaian, sebagai berikut:

a. periode ketika berlakunya peraturan dan/atau ketentuan yang konsisten terkait akuntansi pajak penghasilan; dan

b. periode ketika berlakunya tarif PPh Badan terakhir.

\subsection{Variabel Penelitian dan Definisi Operasional Variabel dan Cara Pengukuran}

\subsubsection{Variabel Independen}

Variabel independen dalam penelitian ini mengikuti Chyz dan Gaertner (2016), antara lain:

1. Low Tax Indicator yang merupakan variabel dummy. Low Tax Indicator diberikan 1 jika ETR atau Cash ETR perusahaan berada pada kuintil terendah, selain itu 0; dan

2. High Tax Indicator yang merupakan variable dummy. High Tax Indicator diberikan 1 jika ETR atau Cash ETR perusahaan berada pada kuintil tertinggi, selain itu 0 .

\subsubsection{Variabel Dependen}

Variabel dependen dalam penelitian ini adalah Pemberhentian Direktur Utama (Forced Turnover President Director) yang merupakan variabel dummy. Forced Turnover President Director diberikan 1 jika pada tahun-perusahaan terjadi pemberhentian direktur utama, selain itu 0. Forced Turnover President Director diketahui dari terjadinya perubahan direktur utama bukan karena direktur utama meninggal dunia atau memasuki usia pensiun (Chyz dan Gaertner, 2016, h. 3) dan (Fee, Hadlock dan Pierce, 2013, h. 568) atau direktur utama menjadi salah satu dari komisaris, wakil komisaris ataupun komisaris utama perusahaan.

\subsubsection{Variabel Kontrol}

Definisi operasional dan cara pengukuran variabel kontrol dalam penelitian ini mengikuti Chyz dan Gaertner (2016), antara lain:

1. Ukuran (size) (Rp miliar) adalah variabel kontrol yang menggambarkan pengaruh dari ukuran perusahaan terhadap pemberhentian direktur utama. Ukuran (Rp miliar) diukur dengan logaritma natural dari nilai pasar ekuitas.

2. $\triangle$ Pengembalian atas Aset ( $\triangle$ return on assets/ROA) adalah variabel kontrol yang menggambarkan pengaruh dari tingkat ROA perusahaan terhadap pemberhentian direktur utama. $\triangle R O A$ merupakan hasil pengurangan dari $R O A$ tahun berjalan dan $R O A$ tahun sebelumnya. 
3. Daya Ungkit (Leverage) adalah variabel kontrol untuk melihat kecenderungan tingginya hutang terhadap pemberhentian direktur utama. Leverage diukur dengan membandingkan long term debt terhadap total asset.

4. $\triangle$ Penjualan ( $\triangle$ Sales) adalah variabel kontrol yang menggambarkan pengaruh dari tingkat sales terhadap pemberhentian direktur utama. $\triangle$ Sales diukur dari besarnya perubahaan sales selama satu tahun dibagi dengan total asset.

5. SPengembalian atas Aset ( $\delta R O A)$ adalah variabel kontrol yang menggambarkan pengaruh tingkat $R O A$ perusahaan terhadap pemberhentian direktur utama. $\delta R O A$ adalah standar deviasi dari $R O A$ selama tiga tahun.

6. $\triangle N O L$ adalah variabel kontrol yang menggambarkan pengaruh dari tingkat rugi pajak tahun sebelumnya (tax loss carryforward) terhadap pemberhentian direktur utama. $\triangle N O L$ diukur dari hasil pengurangan total tax loss carryforward tahun berjalan dan total tax loss carryforward sebelumnya.

7. Indikator Kerugian (Prior Losses Indicator) adalah variabel kontrol yang menggambarkan pengaruh

\subsubsection{Variabel Kontrol}

Berdasarkan hipotesis yang dibangun dalam landasan teori dan variabel-variabel yang telah disebutkan kerugian tahun berjalan ataupun kerugian tahun sebelumnya terhadap pemberhentian direktur utama. Prior Losses Indicator adalah variabel biner. Diberikan 1 jika terdapat tax loss carryforward baik pada tahun berjalan maupun pada tahun sebelumnya, selain itu 0.

8. Proporsi Saham Direktur Utama (President Director Share) adalah variabel kontrol yang menggambarkan pengaruh proporsi saham yang dimiliki oleh seorang direktur utama terhadap pemberhentian direktur utama. President Director Share diukur dari jumlah lembar saham yang dimiliki oleh seorang direktur utama dibagi dengan total saham beredar pada sebuah perusahaan.

9. Kemampuan Manajerial (Managerial Ability) adalah variabel kontrol yang menggambarkan

pengaruh kemampuan manajemen terhadap pemberhentian direktur utama. Managerial Ability diukur dengan mengadopsi penelitian Demerjian, Lev dan McVay (2012), dimana Managerial Ability merupakan hasil regresi dari efisiensi perusahaan (firm efficiency) yang diukur dari perhitungan total asset, market share, free cash flow, age firm, business segmentation, dan foreign currencies.

dalam bagian sebelumnya, penulis mengusulkan model penelitian awal sebagai berikut: 


$$
\text { Forced_Dir }{ }_{i t}=\alpha_{0}+\beta_{1} L_{-} T a x_{i, t}+\beta_{2} H_{-} T a x_{i, t}+\beta_{k} \text { Kontrol }_{i t}+\varepsilon_{i t}
$$

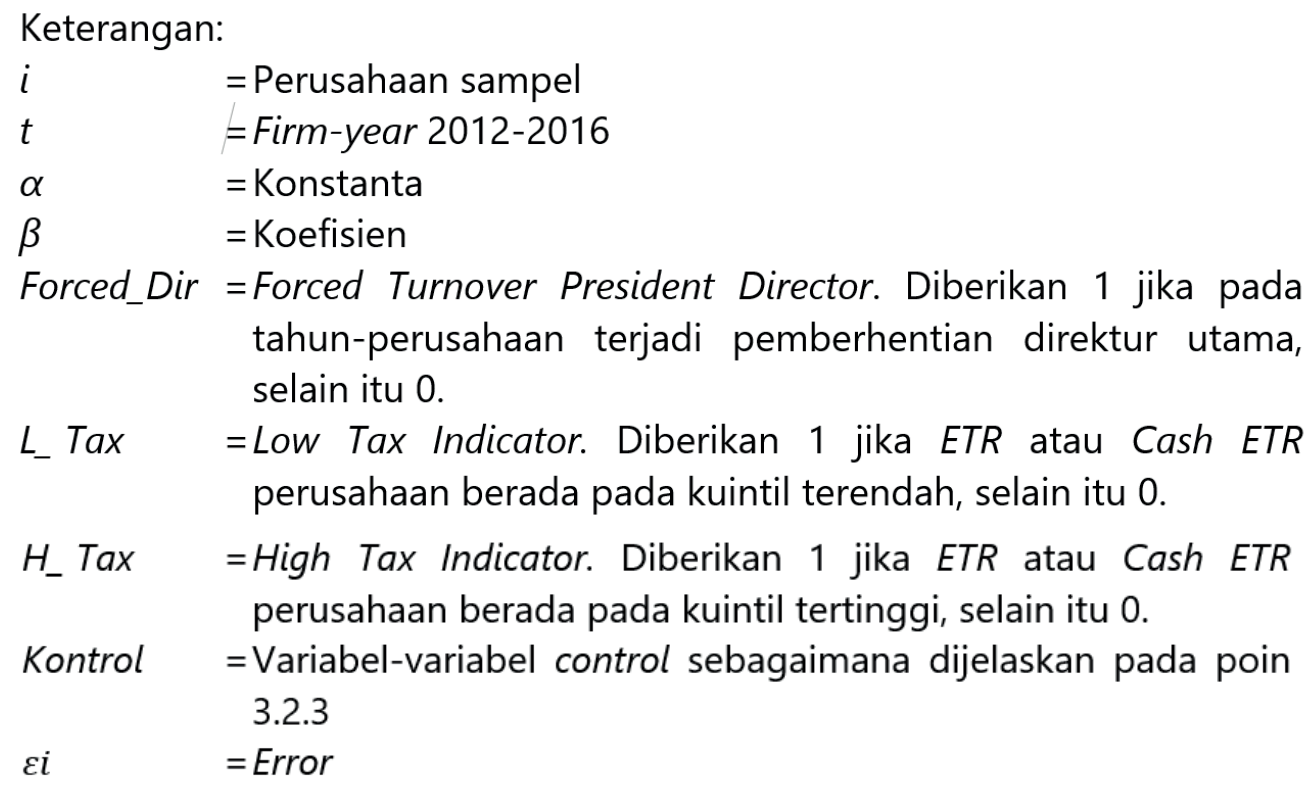

\section{HASIL DAN PEMBAHASAN}

\subsection{Hasil Pemilihan Sampel}

Pengambilan sampel dilakukan secara purposive sampling (judgement sampling). Proses seleksi dilakukan terhadap seluruh data emiten dari sektor-sektor industri yang terdaftar di Bursa Efek Indonesia (BEI) mulai dari tahun 2010 s.d. 2016. Seluruh data, yang sekaligus menjadi populasi dari penelitian ini, diseleksi secara bertahap sesuai dengan kriteria yang telah dijelaskan pada poin 3.1. Proses seleksi secara purposive sampling dalam penelitian ini dilakukan sebanyak sepuluh tahap.

Proses seleksi tahap pertama dilakukan dengan mengeliminasi perusahaan yang termasuk ke dalam sektor keuangan (financial) karena
Proses seleksi tahap kedua dilakukan dengan mengeliminasi perusahaan yang mayoritas penghasilannya dikenakan PPh Final karena perusahaan-perusahaan tersebut memiliki tingkat pajak efektif perusahaan yang berbeda. Proses seleksi tahap ketiga dilakukan dengan mengeliminasi perusahaan yang memiliki pendapatan sebelum pajak (pre-tax income) negatif karena adanya kesulitan untuk menginterpretasikan tingkat pajak efektif pada perusahaan yang mengalami kerugian (Chyz dan Gaertner, 2016, h. 14). Proses seleksi tahap keempat dilakukan dengan mengeliminasi perusahaan yang tidak menyampaikan laporan keuangan secara lengkap karena data perusahaan yang tidak lengkap akan membuat 
data penelitian menjadi tidak seimbang (unbalanced) (Lois Sayrs dalam Yaffee, 2005, hh. 2-3). Proses seleksi tahap

\section{kelima} dilakukan

dengan

mengeliminasi perusahaan yang termasuk sebagai perusahaan kecil dan menengah (small and medium enterprise), karena perusahaanperusahaan tersebut cenderung menghasilkan data keuangan yang tidak wajar (the presence of noise in the accounting data) (Strebulaev dan Yang, 2013, h. 6). Pasal 6 ayat (2) huruf a dan ayat (3) huruf a Undang-Undang Nomor 20 Tahun 2008 menyebutkan bahwa kriteria perusahaan kecil adalah perusahaan yang memiliki kekayaan bersih paling banyak Rp500.000.000 dan kriteria perusahaan menengah adalah perusahaan yang memiliki kekayaan bersih paling banyak Rp10.000.000.000. Proses seleksi tahap keenam dilakukan dengan

mengeliminasi perusahaan asing (foreign company) karena pemegang saham asing dapat mengalami kesulitan untuk memantau kinerja direktur utama yang disebabkan oleh adanya informasi yang asimetris, sehingga pergantian direktur utama pada perusahaan asing lebih kecil kemungkinan terjadinya dibandingkan dengan pergantian direktur utama pada perusahaan domestik (Eisenhardt, 1989); (Nilakant dan Rao, 1994); (Zajac dan Westphal, 1994); serta (Sanders dan Carpenter, 1998). Di Indonesia, perusahaan asing dapat berbentuk Penanaman Modal Asing (PMA). Berturut-turut proses seleksi tahap ketujuh dan tahap kedelapan dilakukan dengan mengeliminasi perusahaan yang memiliki ekuitas (equity) negatif dan ukuran (size) tidak diketahui karena tidak cukup meyakinkan untuk digunakan dalam perhitungan variabel pada model digunakan (Chyz dan Gaertner, 2016, h. 14). Proses seleksi tahap kesembilan dilakukan dengan mengeliminasi perusahaan yang ETR atau Cash ETR tidak diketahui karena keduanya merupakan alat ukur paling lazim digunakan dewan perusahaan untuk menilai kinerja dan pengambilan keputusan direktur utama (Armstrong et al., 2015, h. 1). Terakhir, proses seleksi kesepuluh dilakukan dengan mengeliminasi perusahaan yang Kemampuan Manajerial (Managerial Ability) tidak diketahui karena Managerial Ability dipandang sebagai tingkat keahlian manajer dalam melakukan efisiensi sumber daya perusahaan (Demerjian, Lev dan McVay, 2012). Efisiensi tersebut direfleksikan dari data-data total asset, market share, free cash flow, age firm, business segmentation, dan foreign currencies.

Periode sampel yang digunakan dalam penelitian ini adalah periode ketika kebijakan akuntansi atas PPh telah konsisten (tidak terdapat perubahan yang signifikan atas PPh badan) yaitu periode setelah berlakunya Pernyataan Standar Akuntansi Keuangan (PSAK) 46 Tentang Akuntansi PPh; serta, pada periode ketika berlakunya tarif PPh Badan terakhir (25\%). Oleh karena itu tahun-perusahaan observasi yang digunakan dalam penelitian ini adalah selama 4 tahun (mulai dari 2013 sampai dengan 2017) untuk variabel dependen; serta, selama 4 tahun (mulai dari 2012 sampai dengan 2016) untuk variabel independen dan variabel kontrol. 
Tabel 1. Hasil Pemilihan Sampel dengan Purposive Sampling

Sumber: Diolah dari laporan keuangan di BEI tahun 2012 s.d. 2016

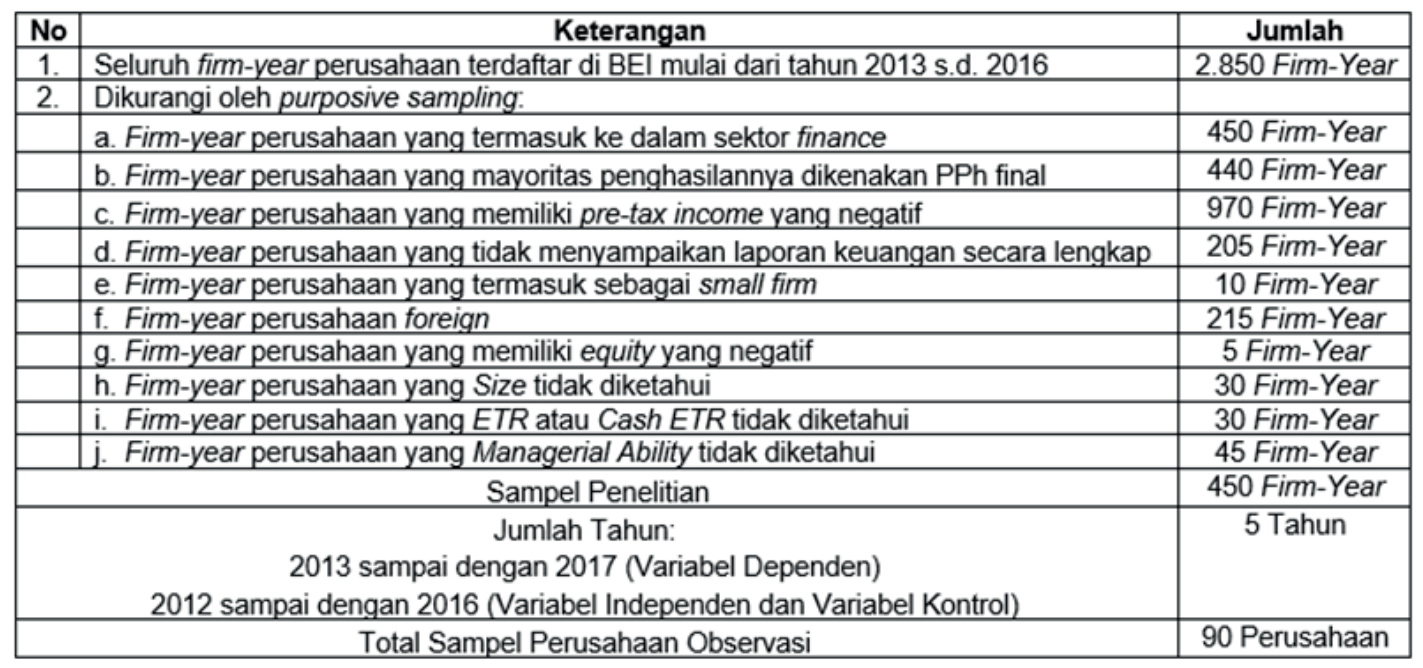

\subsection{Analisis Statistik Deskriptif}

\begin{tabular}{llll} 
Hasil analisis statistik deskriptif & berdasarkan ETR & \multicolumn{1}{c}{ Quintiles } \\
penelitian ini akan disajikan & diinterpretasikan dalam Tabel 2 (Quintile \\
berdasarkan dua jenis kuintil tingkat & 1), Tabel 3 (Quintile 2, 3, dan 4) dan Tabel \\
pajak efektif, yaitu statistik deskriptif & 4 (Quintile 5). Statistik deskriptif penelitian \\
penelitian berdasarkan ETR Quintiles & berdasarkan Cash ETR Quintiles \\
dan statistik deskriptif penelitian & diinterpretasikan dalam Tabel 5 (Quintile \\
berdasarkan Cash ETR Quintiles. & 1), Tabel 6 (Quintile 2, 3, dan 4) dan Tabel \\
Statistik deskriptif & penelitian & 7 (Quintile 5).
\end{tabular}

Tabel 2. Statistik Deskriptif ETR Quintiles 1

Sumber: Penulis (Diolah dari laporan keuangan di BEI tahun 2012 s.d. 2016)

\begin{tabular}{|c|c|c|c|c|c|}
\hline & \multicolumn{5}{|c|}{ ETR Quintile pada Quintile 1} \\
\hline & \multicolumn{5}{|c|}{$\mathbf{n}=\mathbf{1 0 5}$} \\
\hline Variabel & Mean & Std. Dev & Std. Error & Min & $\operatorname{Max}$ \\
\hline Forced_Dir & 0,0286 & 0,1674 & 0,0163 & 0,0000 & 1,0000 \\
\hline Raw ETR & 0,1189 & 0,1286 & 0,0126 & $-0,3599$ & 0,4591 \\
\hline ETR & 0,1274 & 0,1127 & 0,0110 & 0,0000 & 0,4591 \\
\hline Size & 7,2284 & 2,1172 & 0,2066 & 2,9368 & 11,8876 \\
\hline Change_ROA & $-0,0017$ & 0,0618 & 0,0060 & $-0,2606$ & 0,2687 \\
\hline Lev & 0,0907 & 0,1192 & 0,0116 & 0,0000 & 0,5689 \\
\hline Change_Sales & 0,0961 & 0,2183 & 0,0213 & $-0,2876$ & 1,5393 \\
\hline Dev_ROA & 0,0264 & 0,0306 & 0,0030 & 0,0007 & 0,1551 \\
\hline Change_NOL & $-0,0004$ & 0,0057 & 0,0006 & $-0,0257$ & 0,0356 \\
\hline Prior_Loss & 0,2857 & 0,4539 & 0,0443 & 0,0000 & 1,0000 \\
\hline Man_Ability & 0,0481 & 0,3665 & 0,0358 & $-0,6163$ & 0,6496 \\
\hline Dirut_Share & 0,0162 & 0,0593 & 0,0058 & 0,0000 & 0,5017 \\
\hline
\end{tabular}


Tabel 3. Statistik Deskriptif ETR Quintiles 2, 3, dan 4

Sumber: Penulis (Diolah dari laporan keuangan di BEI tahun 2012 s.d. 2016)

\begin{tabular}{|l|c|c|c|c|c|}
\hline & \multicolumn{5}{|c|}{ ETR Quintile pada Quintile 2, 3, dan 4 } \\
\hline & & \multicolumn{5}{|c|}{ n 240 } \\
\hline Variabel & Mean & Std. Dev & Std. Error & Min & Max \\
\hline Forced_Dir & 0,0500 & 0,2184 & 0,0141 & 0,0000 & 1,0000 \\
\hline RawETR & 0,2393 & 0,0606 & 0,0039 & $-0,3599$ & 0,4591 \\
\hline ETR & 0,2393 & 0,0606 & 0,0039 & 0,0000 & 0,4591 \\
\hline Size & 7,6482 & 2,2603 & 0,1459 & 2,9368 & 11,8876 \\
\hline Change_ROA & $-0,0075$ & 0,0470 & 0,0030 & $-0,2606$ & 0,2687 \\
\hline Lev & 0,1005 & 0,1159 & 0,0075 & 0,0000 & 0,5689 \\
\hline Change_Sales & 0,1142 & 0,3549 & 0,0229 & $-0,2876$ & 1,5393 \\
\hline Dev_ROA & 0,0266 & 0,0315 & 0,0020 & 0,0007 & 0,1551 \\
\hline Change_NOL & $-0,0122$ & 0,1952 & 0,0126 & $-0,0257$ & 0,0356 \\
\hline Prior_LOSS & 0,2875 & 0,4535 & 0,0293 & 0,0000 & 1,0000 \\
\hline Man_Ability & $-0,0118$ & 0,3621 & 0,0234 & $-0,6163$ & 0,6496 \\
\hline Dirut_Share & 0,0222 & 0,0747 & 0,0048 & 0,0000 & 0,5017 \\
\hline
\end{tabular}

Tabel 4. Statistik Deskriptif ETR Quintiles 5

Sumber: Penulis (Diolah dari laporan keuangan di BEI tahun 2012 s.d. 2016)

\begin{tabular}{|l|c|c|c|c|c|}
\hline & \multicolumn{5}{|c|}{ ETR Quintile pada Quintile 5 } \\
\hline & \multicolumn{5}{|c|}{$\mathbf{n}=\mathbf{1 0 5}$} \\
\hline \multicolumn{1}{|c|}{ Variabel } & Mean & Std. Dev & Std. Error & Min & Max \\
\hline Forced_Dir & 0,0762 & 0,2666 & 0,0260 & 0,0000 & 1,0000 \\
\hline RawETR & 0,3882 & 0,2285 & 0,0223 & $-0,2340$ & 1,8251 \\
\hline ETR & 0,3822 & 0,1819 & 0,0177 & 0,0000 & 1,0000 \\
\hline Size & 7,2072 & 2,0071 & 0,1959 & 3,3015 & 11,6682 \\
\hline Change_ROA & 0,0004 & 0,0271 & 0,0026 & $-0,0620$ & 0,1173 \\
\hline Lev & 0,0955 & 0,1015 & 0,0099 & 0,0000 & 0,5497 \\
\hline Change_Sales & 0,1428 & 0,1959 & 0,0191 & $-0,2152$ & 1,0519 \\
\hline Dev_ROA & 0,0191 & 0,0177 & 0,0017 & 0,0006 & 0,1431 \\
\hline Change_NOL & $-0,0044$ & 0,0468 & 0,0046 & $-0,4786$ & 0,0090 \\
\hline Prior_LoSS & 0,2857 & 0,4539 & 0,0443 & 0,0000 & 1,0000 \\
\hline Man_Ability & $-0,0211$ & 0,3457 & 0,0337 & $-0,5165$ & 0,5845 \\
\hline Dirut_Share & 0,0165 & 0,0597 & 0,0058 & 0,0000 & 0,5224 \\
\hline
\end{tabular}

Tabel 5. Statistik Deskriptif Cash ETR Quintiles 1

Sumber: Penulis (Diolah dari laporan keuangan di BEl tahun 2012 s.d. 2016)

\begin{tabular}{|l|r|r|r|r|r|}
\hline & \multicolumn{5}{|c|}{ Cash ETR Quintile pada Quintile 1 } \\
\hline & \multicolumn{5}{|c|}{$\mathbf{n = 1 0 5}$} \\
\hline Variabel & Mean & Std. Dev & \multicolumn{1}{|c|}{ Std. Error } & \multicolumn{1}{c|}{ Min } & \multicolumn{1}{c|}{ Max } \\
\hline Forced_Dir & 0,0476 & 0,2140 & 0,0209 & 0,0000 & 1,0000 \\
\hline Raw Cash ETR & 0,1072 & 0,1595 & 0,0156 & $-0,4017$ & 0,6248 \\
\hline Cash ETR & 0,1255 & 0,1241 & 0,0121 & 0,0000 & 0,6248 \\
\hline Size & 7,2902 & 2,1581 & 0,2106 & 3,8286 & 11,8876 \\
\hline Change_ROA & $-0,0068$ & 0,0487 & 0,0048 & $-0,2606$ & 0,2687 \\
\hline Lev & 0,0902 & 0,1087 & 0,0106 & 0,0000 & 0,3881 \\
\hline Change_Sales & 0,0930 & 0,1673 & 0,0163 & $-0,6713$ & 0,5676 \\
\hline Dev_ROA & 0,0253 & 0,0287 & 0,0028 & 0,0014 & 0,1551 \\
\hline Change_NOL & $-0,0004$ & 0,0050 & 0,0005 & $-0,0257$ & 0,0305 \\
\hline Prior_LOSS & 0,2952 & 0,4583 & 0,0447 & 0,0000 & 1,0000 \\
\hline Man_Ability & 0,0244 & 0,3463 & 0,0338 & $-0,5846$ & 0,5980 \\
\hline Dirut_Share & 0,0139 & 0,0377 & 0,0037 & 0,0000 & 0,2288 \\
\hline
\end{tabular}


Tabel 6. Statistik Deskriptif Cash ETR Quintiles 1, 2, dan 4

Sumber: Penulis (Diolah dari laporan keuangan di BEI tahun 2012 s.d. 2016)

\begin{tabular}{|l|c|c|c|c|c|}
\hline & \multicolumn{5}{|c|}{ n=240 } \\
\hline & \multicolumn{5}{|c|}{ Cash ETR pada Quintile 2, 3, dan 4 } \\
\hline Variabel & Mean & Std. Dev & Std. Error & Min & Max \\
\hline Forced_Dir & 0,0500 & 0,2184 & 0,0141 & 0,0000 & 1,0000 \\
\hline Raw Cash ETR & 0,2756 & 0,0932 & 0,0060 & $-0,4017$ & 0,6248 \\
\hline Cash ETR & 0,2756 & 0,0932 & 0,0060 & 0,0000 & 0,6248 \\
\hline Size & 7,6268 & 2,2434 & 0,1448 & 3,8286 & 11,8876 \\
\hline Change_ROA & $-0,0036$ & 0,0530 & 0,0034 & $-0,2606$ & 0,2687 \\
\hline Lev & 0,1059 & 0,1235 & 0,0080 & 0,0000 & 0,3881 \\
\hline Change_Sales & 0,1134 & 0,3555 & 0,0229 & $-0,6713$ & 0,5676 \\
\hline Dev_ROA & 0,0270 & 0,0320 & 0,0021 & 0,0014 & 0,1551 \\
\hline Change_NOL & $-0,0145$ & 0,1974 & 0,0127 & $-0,0257$ & 0,0305 \\
\hline Prior_LOSs & 0,2625 & 0,4409 & 0,0285 & 0,0000 & 1,0000 \\
\hline Man_Ability & 0,0006 & 0,3560 & 0,0230 & $-0,5846$ & 0,5980 \\
\hline Dirut_Share & 0,0264 & 0,0866 & 0,0056 & 0,0000 & 0,2288 \\
\hline
\end{tabular}

Tabel 7. Statistik Deskriptif Cash ETR Quintiles 5

Sumber: Penulis (Diolah dari laporan keuangan di BEl tahun 2012 s.d. 2016)

\begin{tabular}{|l|c|c|c|c|c|}
\hline & \multicolumn{5}{|c|}{ Cash ETR pada Quintile 5 } \\
\hline & \multicolumn{5}{|c|}{ n=105 } \\
\hline Variabel & Mean & Std. Dev & Std. Error & Min & Max \\
\hline Forced_Dir & 0,0571 & 0,2332 & 0,0228 & 0,0000 & 1,0000 \\
\hline Raw Cash ETR & 0,6344 & 0,5035 & 0,0491 & 0,1136 & 3,6687 \\
\hline Cash ETR & 0,5492 & 0,2687 & 0,0262 & 0,1136 & 1,0000 \\
\hline Size & 7,1943 & 2,0159 & 0,1967 & 3,5001 & 11,6219 \\
\hline Change_ROA & $-0,0035$ & 0,0290 & 0,0028 & $-0,0882$ & 0,0932 \\
\hline Lev & 0,0838 & 0,0905 & 0,0088 & 0,0000 & 0,3338 \\
\hline Change_Sales & 0,1479 & 0,2380 & 0,0232 & $-0,5567$ & 1,0519 \\
\hline Dev_ROA & 0,0195 & 0,0190 & 0,0019 & 0,0006 & 0,1431 \\
\hline Change_NOL & 0,0008 & 0,0063 & 0,0006 & $-0,0193$ & 0,0370 \\
\hline Prior_LOSS & 0,3333 & 0,4737 & 0,0462 & 0,0000 & 1,0000 \\
\hline Man_Ability & $-0,0258$ & 0,3818 & 0,0373 & $-0,6081$ & 0,5845 \\
\hline Dirut_Share & 0,0093 & 0,0326 & 0,0032 & 0,0000 & 0,2164 \\
\hline & & & & & \\
\hline
\end{tabular}

\subsection{Hasil Pengolahan Data dan Pengujian Hipotesis}

Penelitian ini bertujuan untuk mengetahui bagaimana pengaruh tingkat pajak efektif (baik ETR maupun Cash ETR) perusahaan yang terlalu rendah atau terlalu tinggi terhadap pemberhentian manajer puncak. Sesuai dengan hipotesis penelitian, pengujian hipotesis dilakukan secara parsial. Adapun pendekatan statistik yang digunakan untuk memperoleh hasil uji pengolahan adalah dengan menggunakan Hasil uji Signifikan Parameter Individual/Parsial (Uji-t). 


\subsubsection{Pengaruh ETR terhadap \\ Pemberhentian Direktur Utama}

Berdasarkan hasil uji pengolahan pada Tabel 8, variabel L_Tax dan H_Tax memiliki nilai prob. sebesar 0,3322 dan 0,9922 . Nilai probabilitas tersebut lebih besar daripada signifikansi 0,05. Oleh karena itu, hasil pengujian ini mengarahkan pada keputusan menolak $\mathrm{Ha} 1$ dan $\mathrm{Ha} 2$, sehingga dapat disimpulkan bahwa pajak yang terlalu rendah ataupun pajak yang terlalu tinggi pada ETR Quintiles berpengaruh tidak signifikan terhadap pemberhentian direktur utama.

Tabel 8. Hasil Uji ETR Quintiles

Sumber: Penulis (Diolah dari Output Eviews 10 SV)

\begin{tabular}{|c|c|c|c|c|}
\hline Variable & Coefficient & Std. Error & t-Statis tic & Prob. \\
\hline$\stackrel{\text { C }}{\text { L_TAX }}$ & $\begin{array}{r}0.469239 \\
-0.034085\end{array}$ & $\begin{array}{l}0.188368 \\
0.035102\end{array}$ & $\begin{array}{r}2.491075 \\
-0.971018\end{array}$ & $\begin{array}{l}0.0132 \\
0.3322\end{array}$ \\
\hline H_TAX & 0.000361 & 0.036882 & 0.009838 & 0.9922 \\
\hline CHANGE_NOL & 0.162022 & 0.081754 & 1.981830 & 0.0483 \\
\hline CHANGE_ROA & -0.002983 & 0.224871 & -0.013287 & 0.9894 \\
\hline CHANGE_SALES & -0.039822 & 0.039540 & -1.007145 & 0.3146 \\
\hline DEV_ROA & 1.040286 & 0.568571 & 1.836107 & 0.0672 \\
\hline DIRUT_SHARE & -0.018270 & 0.449410 & -0.040653 & 0.9676 \\
\hline LEV & -0.000616 & 0.227631 & -0.002705 & 0.9978 \\
\hline MAN_ABILITY & -0.098744 & 0.136051 & -0.711083 & 0.4775 \\
\hline PRIOR_LOSS & 0.025181 & 0.060632 & 0.415313 & 0.6782 \\
\hline SIZ̄E & -0.058682 & 0.024681 & -2.377611 & 0.0180 \\
\hline \multicolumn{5}{|c|}{ Effects Specification } \\
\hline \multicolumn{5}{|c|}{ Cros s-s ection fixed (dummy variables) } \\
\hline R-s quared & 0.297131 & \multicolumn{2}{|c|}{ Mean dependent var } & 0.051111 \\
\hline Adjus ted R-s quared & 0.095736 & \multirow{2}{*}{\multicolumn{2}{|c|}{$\begin{array}{l}\text { S.D. dependent var } \\
\text { A.raike info criterion }\end{array}$}} & 0.220469 \\
\hline S.E. of regres s ion & 0.209851 & & & -0.092035 \\
\hline Sum s quared res id & 15.33973 & \multicolumn{2}{|c|}{ Schw arz criterion } & 0.830262 \\
\hline Log likelihood & 121.7080 & \multirow{2}{*}{\multicolumn{2}{|c|}{ Hannan-Quinn oriter. }} & 0.271477 \\
\hline F-s tatis tic & 1.475361 & & Durbin-Wats on s tat & 2.777084 \\
\hline Prob(F-s tatis tic) & 0.005621 & & & \\
\hline
\end{tabular}

\subsubsection{Pengaruh Cash ETR terhadap Pemberhentian Direktur Utama}

Berdasarkan hasil uji pengolahan pada Tabel 9, variabel L_Tax dan H_Tax memiliki nilai prob. sebesar 0,1128 dan 0,6537 . Nilai probabilitas tersebut lebih besar daripada signifikansi 0,05. Oleh karena itu, hasil pengujian ini mengarahkan pada keputusan menolak $\mathrm{Ha} 1$ dan $\mathrm{Ha} 2$, sehingga dapat disimpulkan bahwa baik pajak yang terlalu rendah atau pajak terlalu tinggi pada Cash ETR Quintiles berpengaruh tidak signifikan terhadap pemberhentian direktur utama. 
Tabel 9. Hasil Uji Cash ETR Quintiles

Sumber: Penulis (Diolah dari Output Eviews 10 SV)

\begin{tabular}{crrrr} 
Variable & Coeficient & Std. Error & t-Statistic & Prob. \\
\hline \hline C & 0.470433 & 0.182573 & 2.576687 & 0.0104 \\
L_TAX & -0.064555 & 0.040605 & -1.589811 & 0.1128 \\
CHANGE_NOL & -0.016204 & 0.036087 & -0.449045 & 0.6537 \\
CHANGE_ROA & 0.177851 & 0.082428 & 2.157666 & 0.0316 \\
CHANGE_SALES & 0.014356 & 0.224739 & 0.063878 & 0.9491 \\
DEV_ROA & -0.036059 & 0.039823 & -0.905484 & 0.3658 \\
DIRUT_SHARE & 1.103814 & 0.567339 & 1.945601 & 0.0525 \\
LEV & 0.024075 & 0.453714 & 0.053062 & 0.9577 \\
MAN_ABILITY & 0.012990 & 0.227187 & 0.057178 & 0.9544 \\
PRIOR_LOSS & -0.117281 & 0.136101 & -0.861719 & 0.3894 \\
SIZZ & 0.016013 & 0.059799 & 0.267783 & 0.7890 \\
& -0.057549 & 0.024192 & -2.378804 & 0.0179 \\
\hline \hline & Effects Specification & & \\
\hline Cross-section fxed (dummy variables) & & & \\
\hline R-squared & 0.300190 & Mean dependent var & 0.051111 \\
Adjusted R-squared & 0.099672 & S.D. dependent var & 0.220469 \\
S.E. of regression & 0.209194 & Akaike info criterion & -0.096398 \\
Sum squared resid & 15.27296 & Schwarz criterion & 0.825900 \\
Log likelihood & 122.6894 & Hannan-Quinn criter. & 0.267114 \\
F-statistic & 1.497069 & Durbin-Watson stat & 2.782159 \\
Prob(F-statistic) & 0.004240 & &
\end{tabular}

\subsubsection{Pengaruh Cash ETR terhadap \\ Pemberhentian Direktur Utama}

Hasil pengujian hipotesis penelitian ini tidak selaras dengan penelitian Chyz dan Gaertner (2016, hh. 34-35) yang menyimpulkan bahwa bahwa baik ETR maupun Cash ETR perusahaan yang terlalu rendah berpengaruh terhadap pemberhentian manajer puncak. Perbedaan hasil penelitian ini dengan hasil penelitian Chyz dan Gaertner (2016, hh. 34-35) dapat disebabkan oleh dua hal. Pertama, hasil penelitian Blouin (2014, hh. 875-876) yang menyatakan bahwa tax planning dianggap menguntungkan pemegang saham karena tax planning menghasilkan arus kas dan laba bersih yang lebih tinggi, sehingga perusahaan memiliki tanggung jawab untuk meminimalisir pajak yang timbul. Balter dalam Zain (2008, h. 1) menyimpulkan bahwa tax planning adalah proses mengorganisasi usaha wajib pajak atau sekelompok wajib pajak sedemikian rupa sehingga utang pajaknya, baik PPh maupun pajak lainnya, berada dalam posisi yang paling minimal, sepanjang hal ini dimungkinkan oleh perundangundangan perpajakan. Para pemegang saham cenderung menginginkan perusahaan untuk melakukan tax planning yang optimal sehingga berdampak pada rendahnya tingkat pajak efektif perusahaan. Hal tersebut didukung oleh penelitian yang dilakukan oleh Hanlon dan Heitzman dalam Chyz dan Gaertner (2016, h. 10) yang menyimpulkan bahwa 
para pemegang saham cenderung mengharapkan manajer puncak untuk mengurangi kewajiban pajak yang timbul sebab pajak merupakan transfer kekayaan dari pemegang saham kepada otoritas pemerintah. Sementara itu Fee, Hadlock dan Pierce (2013, hh. 577-578) membuktikan bahwa pemberhentian manajer puncak merupakan tindakan yang secara sengaja diambil untuk mengubah arah, strategi, dan kepemimpinan perusahaan. Oleh karena itu dapat disimpulkan bahwa para pemegang saham pada perusahaan go public di Indonesia cenderung menginginkan direktur utama untuk melakukan tax planning yang optimal sehingga arus kas dan laba bersih yang dihasilkan oleh perusahaan lebih tinggi, sehingga tingkat pajak efektif perusahaan yang terlalu rendah tidak berpengaruh terhadap kemungkinan pemberhentian direktur utama.

Kedua, hasil penelitian Gallemore et al. (2012, hh. 31-33) yang menyatakan bahwa kegiatan penampungan pajak (tax shelter) tidak mempengaruhi peningkatan kemungkinan pemberhentian seorang manajer puncak. US Congress mendefinisikan tax shelter, yang merupakan tax planning, sebagai pengaturan sedemikian rupa untuk menghindari pengenaan pajak dengan membuat keuntungan ekonomi tanpa adanya kerugian dan risiko ekonomi (Bppk.kemenkeu.go.id, 19 September 2017). Praktik tax shelter bertujuan untuk mengurangi penghasilan kena pajak yang mengakibatkan pengurangan pembayaran beban pajak.
Hasil penelitian Gallemore, Maydew dan Thornock (2012), yang dilakukan terhadap 113 perusahaan non-asing dengan firm-year penelitian 1995 sampai dengan 2005, membuktikan bahwa praktik tax shelter yang dilakukan oleh manajer puncak, yang menyebabkan berkurangnya beban pajak perusahaan dan tingkat pajak efektif perusahaan terlalu rendah, tidak berpengaruh terhadap kemungkinan pemberhentian manajer puncak. Gallemore, Maydew dan Thornock (2014, h. 1127) menunjukkan bahwa manajer puncak tidak menanggung biaya reputasi dari kebijakan pajak yang agresif yang diterapkan oleh perusahaan. Oleh karena itu dapat disimpulkan bahwa baik praktik pengurangan maupun praktik penghindaran pajak perusahaan yang dilakukan oleh perusahaan go public di Indonesia, yang menyebabkan berkurangnya beban pajak perusahaan dan tingkat pajak efektif perusahaan terlalu rendah, tidak berpengaruh terhadap kemungkinan pemberhentian direktur utama.

\subsubsection{Pengaruh Cash ETR terhadap Pemberhentian Direktur Utama}

Hasil pengujian hipotesis penelitian ini tidak selaras dengan penelitian Chyz dan Gaertner (2016, hh. 34-35) yang menyimpulkan bahwa bahwa baik ETR maupun Cash ETR perusahaan yang terlalu tinggi berpengaruh terhadap pemberhentian manajer puncak.

Perbedaan hasil penelitian ini dengan hasil penelitian Chyz dan Gaertner (2016) dapat disebabkan oleh 
jarangnya jabatan manajer puncak diemban oleh seseorang yang ahli di bidang perpajakan. Sebagai akibat dari hal tersebut, manajer puncak bisa jadi hanya memahami sifat kompetitif dari industrinya dan potensi ekspansi untuk menghasilkan skala ekonomi perusahaan yang berbeda tanpa memahami seluk beluk terkait strategi pajak perusahaan (Dyreng, Hanlon dan Maydew 2010, h. 1164). Hasil penelitian Dyreng, Hanlon dan Maydew (2010, h. 1164) menyatakan bahwa seorang manajer puncak dianggap tidak terlibat secara langsung dalam pemilihan dan penerapan strategi pajak karena jabatan manajer puncak jarang diemban oleh seseorang yang ahli dalam perpajakan. Dapat disimpulkan bahwa meskipun manajer puncak mempengaruhi strategi operasional dan keuangan perusahaan secara langsung, mereka tidak mempengaruhi penerapan strategi pajak perusahaan secara langsung sehingga pemegang saham tidak dapat menuntut pertanggungjawaban mereka atas pajak perusahaan. Hasil penelitian Dyreng, Hanlon dan Maydew (2010) yang dilakukan terhadap 1.138 perusahaan dan 908 top executive dengan firm-year 1992-2006, membuktikan tingkat pajak efektif perusahaan tidak berpengaruh terhadap pemberhentian manajer puncak. Oleh karena itu dapat disimpulkan bahwa pajak yang terlalu tinggi pada ETR dan Cash ETR perusahaan go public di Indonesia tidak berpengaruh terhadap kemungkinan pemberhentian direktur utama.

\subsection{Perbedaan Hasil Penelitian}

Perbedaan hasil penelitian ini dengan hasil penelitian Chyz dan Gaertner (2016) dapat disebabkan oleh perbedaan norma sosial (social norms) dan biaya reputasi (reputational cost) antara di Amerika Serikat dan di Indonesia. Kaitan antara norma sosial dan biaya reputasi adalah bahwa di dalam lingkungan dimana norma sosial berfungsi aktif baik manajemen puncak maupun perusahaan akan benar-benar mempertimbangkan biaya reputasi dalam setiap pengambilan keputusan atas strategi pajaknya, sebab masyarakat akan memberikan hukuman atas setiap pelanggaran yang dilakukan oleh perusahaan serta manajemennya. Sebaliknya, lingkungan dimana norma sosial tidak berfungsi aktif baik manajemen puncak maupun perusahaan tidak akan benar-benar mempertimbangkan biaya reputasi dalam setiap pengambilan keputusan atas strategi pajaknya, sebab masyarakat tidak akan memberikan hukuman atas setiap pelanggaran yang dilakukan oleh perusahaan serta manajemennya.

Norma atau kontrol sosial di Amerika Serikat dapat dibuktikan melalui adanya perhatian serius masyarakat Amerika Serikat terhadap kasus pelanggaran yang dilakukan oleh perusahaan-perusahaan besar di Amerika Serikat. Salah satunya: kasus manipulasi laporan keuangan terbesar yang melibatkan Arthur Andersen dan Enron, yang pada 2002 dinyatakan bersalah oleh U.S Department of Justice (Nytimes.com, 16 Januari 2002). 
Chaney dan Philipich (2002, h. 1222) menemukan bahwa terungkapnya kasus tersebut tidak hanya membuat Arthur Andersen dan Enron kehilangan reputasi dan menjadi sorotan tajam dari publik Amerika tetapi juga membuat perusahaan-perusahaan klien Arthur Andersen kehilangan reputasi, yang ditandai dengan turunnya saham perusahaan-perusahaan tersebut secara drastis di bursa efek. Puncak dari kasus tersebut adalah Kenneth Lay, CEO Enron, dan mengundurkan diri pada 2 Januari 2002, sementara Joseph Berandino, CEO Arthur Andersen, mengundurkan diri pada 26 Maret 2002.

Sementara itu, norma atau kontrol sosial di Indonesia tidak berjalan sebagaimana di Amerika Serikat. Hal tersebut dibuktikan melalui kasus pelanggaran yang pernah dilakukan oleh perusahaan-perusahaan besar Indonesia. Salah satunya adalah kasus PT Lapindo Brantas dan semburan lumpur panas yang terjadi sejak 28 Mei 2006 di kawasan Porong, Sidoarjo. Drilling Engineers Club dalam Kompas.com (7 Agustus 2012) menyimpulkan bahwa luapan lumpur di Sidoarjo diakibatkan oleh kesalahan operasional pengeboran yang disengaja atau intentional default oleh PT Lapindo Brantas. Puncak dari kasus tersebut adalah tidak ada satu pun korporasi atau pengelola dari PT Lapindo Brantas yang terkena jeratan hukum, bahkan Mahkamah Agung dan Dewan Perwakilan Rakyat (DPR) menyatakan bahwa kasus tersebut sebagai dampak bencana alam (Cnnindonesia.com, 29 Mei 2015).

\section{KESIMPULAN}

Penelitian ini bertujuan untuk mengetahui bagaimana pengaruh tingkat pajak efektif perusahaan yang terlalu rendah atau terlalu tinggi terhadap pemberhentian manajer puncak. Penelitian ini dilakukan dengan menggunakan sampel berupa 90 perusahaan yang terdaftar di BEI, yang dipilih setelah melalui tahapan purposive sampling, dengan firm-year mulai dari 2012 s.d. 2016.

Berdasarkan rangkaian pengujian dan pembahasan yang telah dilakukan di atas, dapat disimpulkan bahwa baik ETR maupun Cash ETR perusahaan yang terlalu rendah tidak berpengaruh terhadap pemberhentian manajer puncak (direktur utama). Kesimpulan tersebut dapat disebabkan oleh dua hal. Pertama, para pemegang saham cenderung mengharapkan manajer puncak untuk mengurangi kewajiban pajak yang timbul. Pengurangan kewajiban pajak dianggap menguntungkan pemegang saham karena hal tersebut akan menghasilkan arus kas dan laba bersih yang lebih tinggi. Kedua, pemberhentian manajer puncak merupakan tindakan yang secara sengaja diambil oleh para pemegang saham untuk mengubah arah, strategi, dan kepemimpinan perusahaan. Oleh karena itu, ETR perusahaan yang terlalu rendah justru menguntungkan para pemegang saham sehingga para pemegang saham tidak perlu untuk melakukan pemberhentian direktur utama.

Selain itu, hasil kesimpulan juga menunjukkan bahwa baik ETR maupun Cash ETR perusahaan yang terlalu tinggi tidak berpengaruh terhadap 
pemberhentian manajer puncak. Kesimpulan tersebut dapat disebabkan oleh jarangnya jabatan seorang manajer puncak diemban oleh seseorang yang ahli di bidang perpajakan sehingga manajer puncak dianggap tidak terlibat secara langsung dalam pemilihan dan penerapan strategi pajak. Oleh karena itu, para pemegang saham tidak dapat menuntut pertanggungjawaban direktur utama atas ETR dan Cash ETR perusahaan yang terlalu tinggi.

\section{IMPLIKASI DAN KETERBATASAN}

\subsection{Keterbatasan}

Beberapa keterbatasan yang ditemui selama penyelesaian penelitian ini adalah keterbatasan proxy, informasi laporan keuangan dan model penelitian. Proxy untuk tax avoidance yang digunakan dalam penelitian ini adalah tingkat efektif pajak. Hasil penelitian ini bisa jadi berbeda jika menggunakan proxy lain (misal perbedaan - buku - pajak (book-tax-difference/BTD).

Keterbatasan berikutnya adalah laporan keuangan perusahaan tidak menampilkan rincian jangka waktu kontrak kerja yang diemban direktur utama atau presiden direktur sehingga terdapat kesulitan untuk mengidentifikasi apakah manajer puncak berhenti karena masa kontrak kerja telah berakhir (unforced turnover) atau disebabkan oleh keputusan pemegang saham (forced turnover).

Keterbatasan terakhir adalah pengujian utama penulis dalam penelitian ini menggunakan model probabilitas linier (linear probability model/LPM) yaitu estimasi kuadrat terkecil (ordinary least square/OLS) terhadap variabel dependen biner, sebab tujuan utama dari penelitian ini adalah untuk mengetahui apakah tingkat pajak efektif berpengaruh signifikan terhadap pemberhentian direktur utama. Hasil penelitian ini mungkin akan berbeda jika menggunakan model regresi yang memang khusus untuk data biner (misalnya, probit dan logit).

\subsection{Saran}

Berdasarkan pembahasan hasil penelitian, simpulan dan keterbatasan masalah yang telah diuraikan sebelumnya, terdapat beberapa saran yang penulis ingin sampaikan. Saran tersebut ditujukan kepada DJP dan peneliti selanjutnya. Bagi DJP, hasil penelitian ini membuktikan bahwa pemberitaan pemberhentian manajer puncak, baik melalui pemberitaan di media maupun melalui laporan tahunan perusahaan, tidak dapat dijadikan sebagai informasi untuk penyusunan rencana penggalian potensi oleh $A R$ dan sebagai bahan masukan dalam penyusunan rencana pemeriksaan dan program pemeriksaan oleh FPP.

Sementara itu, peneliti selanjutnya dapat menggunakan alat ukur lain sebagai proxy untuk mengukur tax avoidance perusahaan selain tingkat pajak efektif, seperti BTD ataupun tax shelter. Peneliti selanjutnya dapat menggunakan pendekatan dasar perhitungan proxy berbeda untuk mengukur kinerja akuntansi manajer puncak. Selain itu, peneliti selanjutnya dapat menggunakan model regresi yang dirancang khusus untuk data biner, seperti probit atapun logit. 


\section{DAFTAR PUSTAKA}

[1] Armstrong, C. S., Blouin, J. L., Jagolinzer, A. D., and Larcker, D. F. 2015. Corporate Governance, Incentives, and Tax Avoidance. Journal of Accounting and Economics, 60: $1-17$.

[2] Austin, C. and Wilson, R. 2015. Are Reputational Costs A Determinant of Tax Avoidance?. Working Paper: University of South Carolina and University of Oregon.

[3] Bbc.co.uk. 2007. Direksi AAG Resmi Tersangka. http://www.bbc.co.uk/indonesian/news/stor y/2007/11/071108_taxfraud.shtml (Diakses pada tanggal 07 Juli 2018).

[4] Bobek, Donna D., Robin W. Roberts and John T. Sweeney. 2007. The Social Norms of Tax Compliance: Evidence from Australia, Singapore, and The United States. Journal of Business Ethics (74): 49-64.

[5] Bppk.kemenkeu.go.id.

2017. https://bppk.kemenkeu.go.id/content/berit a/balai-diklat-keuangan-medan-pemahama n-tax-planning-2019-11-05-f3dea413/ (Diakses pada tanggal 07 Juli 2018).

[6] Chaney, Paul and Philipich, Kirk. 2002. Shredded Reputation: The Cost of Audit Failure. Journal of Accounting Research Volume40, Issue4 September 2002: 1221-1245.

[7] Chen, C., Huang, Y. L., and Stanfield, J. 2013. The Effect of Hedge Fund Activism on Corporate Tax Avoidance. The Accounting Review, 87: 1493-1526.

[8] Chyz, J. A. and Gaertner, F. B. 2016. Can Paying "Too Much" or "Too Little" Tax Contributing to Forced CEO Turnover?. The Accounting Review, 93: 103-130.

[9] Cnnindonesia.com. 2015. Sudah Ditetapkan DPR Bencana Alam, Lapindo Tak Bisa Dipidana. https://www.cnnindonesia.com/nasional/20 150529134709-20-56529/sudah-ditetapkan -dpr-bencana-alam-lapindo-tak-bisa-dipida na (Diakses pada tanggal 07 Juli 2018).

[10] Crocker, K. J. and Slemrod, J. 2005. Corporate Tax Evasion with Agency Costs. Journal of Public Economics, 89: 1593-1610.
[11] Demerjian, P., B. Lev, and S. McVay. 2012. Quantifying Managerial Ability: A New Measure and Validity Tests. Management Science 58 (7): 1229-1248.

[12] Desai, M. A. and Dharmapala, D. 2006. Corporate Tax Avoidance and High-Powered Incentives. Journal of Financial Economics, 79: 145-179.

[13] Detik.com. 2012. Sudah Ditetapkan DPR Bencana Alam, Lapindo Tak Bisa Dipidana. https://news.detik.com/berita/d-2128520/m a-vonis-kasus-penggelapan-pajak-asian-agr i-bayar-rp-25-t-ke-negara (Diakses pada tanggal 07 Juli 2018).

[14] Dyreng, S., Hanlon, M., and Maydew, E. L. 2010. The Effects of Executives on Corporate Tax Avoidance. The Accounting Review, 85: 1163-1189.

[15] Fee, C. E., Hadlock, C. J. and Pierce, J. R. 2013. Managers With and Without Style: Evidence Using Exogenous Variation. Review of Financial Studies, 26: 567-601.

[16] Gallemore, J., Maydew E. L., and Thornock, J. R. 2014. The Reputational Costs of Tax Avoidance and the UnderSheltering Puzzle. Contemporary Accounting Research, 31: 1103-1133.

[17] Graham, J. R., Hanlon, M., Shevlin, T., and Shroff, N. 2015. Tax Rates and Corporate Decision Making. Working Paper. Duke University, Massachusetts Institute of Technology, and University of California-Irvine.

[18] Hanlon, M., and Slemrod, J. 2009. What Does Tax Aggressiveness Signal? Evidence from Stock Price Reactions to News About Tax Aggressiveness. Journal of Public Economics, 93: 126-141.

[19] Kompas.com. 2012. Pakar: Lumpur Sidoarjo Murni Kesalahan Pengeboran. https://nasional.kompas.com/read/2012/08/ 07/19093138/Pakar.Lumpur.Sidoarjo.Murni.K esalahan.Pengeboran (Diakses pada tanggal 07 Juli 2018).

[20] Lanis, R., and Richardson, G. 2011. The Effect of Board of Director Composition on Corporate Tax Aggressiveness. Journal Accounting and Public Policy, 30: 5070. 
[21] NYTimes.com. 2002. Enron's Collapse: The Overview; Arthur Andersen Fires An Executive for Enron Orders. https://www.nytimes.com/2002/01/16/busin ess/enron-s-collapse-overview-arthur-and ersen-fires-executive-for-enron-orders.htm I (Diakses pada tanggal 07 Juli 2018).

[22] Parlaungan, Gorga. 2017. The Tax Morale of Individual Taxpayers in Indonesia [Tesis]. Australia (AU): Curtin Law School.

[23] Sp.beritasatu.com. 2010. http://sp.beritasatu.com/home/gayus-men gaku-terima-dana-dari-pt-kpc-dan-pt-bum i-resources/1775 (Diakses pada tanggal 07 Juli 2018).

[24] Strebulaev, I., Yang, B. 2013. The Mystery of Zero-Leverage Firms. Journal of Financial Economics (JFE), Forthcoming: 1-59.

[25] Zain, Moh. 2008. Manajemen Perpajakan Edisi 3. Jakarta: Penerbit Salemba Empat. 